\title{
Skrining Senyawa Metabolit Steroid sebagai Hormon Reproduksi Ternak pada Tanaman Katuk dan Jantung Pisang
}

\section{Metabolite Steroid Screening of Katuk and Banana Flower For Reproductive Hormone}

\author{
H. D. Putranto ${ }^{1}$, S. M. Ginting ${ }^{2}$, Nurmeliasari ${ }^{1}$, Y. Yumiati ${ }^{3}$ \\ ${ }^{1}$ Jurusan Peternakan Fakultas Pertanian Universitas Bengkulu, Jalan Raya Kandang Limun, Bengkulu 38371A \\ ${ }^{2}$ Program Studi Pendidikan Kimia Fakultas Keguruan dan Ilmu Pendidikan Universitas Bengkulu \\ ${ }^{3}$ Jurusan Agribisnis Fakultas Pertanian Universitas Dehasen Bengkulu, Jalan Raya Meranti, Sawah Lebar, Bengkulu \\ e-mail : tora_rendai@yahoo.com
}

(Diterima: 15 November 2013; Disetujui: 15 Februari 2014)

\begin{abstract}
ABSTRAK
Indonesia memiliki banyak plasma nutfah berupa tanaman yang berpotensi untuk difungsikan sebagai bahan pakan ternak baik yang diposisikan sebagai bahan pakan utama ataupun suplemen dengan tujuan tertentu. Tanaman katuk (Sauropus androgynus) dalam beragam bentuk dan formulasi telah disuplementasikan untuk meningkatkan status reproduksi ternak. Sedangkan jantung pisang telah lama dipergunakan oleh beberapa kalangan masyarakat guna memperbaiki status reproduksi. Pada penelitian ini beberapa bagian tanaman katuk dan beberapa jenis jantung pisang diuji kandungan senyawa steroidnya (skrining) menggunakan metode Simes et al. Hasil penelitian menunjukkan bahwa tanaman katuk positif mengandung senyawa metabolit steroid $(+)$ baik dari bagian daun $(+)$, batang (+) serta campuran daun dan batang (+). Sedangkan jantung pisang raja, srindit, batu dan jantan seluruhnya negatif mengandung senyawa metabolit steroid (-). Dari hasil skrining fitokimia dapat disimpulkan bahwa tanaman katuk mengandung senyawa metabolit steroid yang berperan penting pada biosintesa hormon steroid ternak betina sedangkan jantung pisang tidak mengandung senyawa metabolit steroid.
\end{abstract}

Kata Kunci: jantung pisang, katuk, senyawa metabolit steroid dan skrining fitokimia

\section{ABSTRACT}

Indonesia had thousand of plasma nutfah potentially to be used as animal feed as well positioned as the main feed ingredient or supplement for specific purposes. Katuk (Sauropus androgynus) in various forms and formulations have been supplemented to increase the reproductive status of some animals. While banana flower has been used rarely by some people to improve reproductive status. In this study, three parts of katuk and four types of banana flowers were tested for its metabolite steroid by using the method of Simes et al. The results showed that katuk positively contains metabolite steroid for its leaves and stem, as well as the mixture of both parts. While banana flowers (raja, srindit, batu and jantan) were negative. To sum up, based on phytochemical screening could result katuk contains metabolite steroid which has an important role in biosynthesis of steroid hormones.

Keywords: Banana flowers, katuk, metabolite steroid, phytochemical screening. 


\section{PENDAHULUAN}

Beberapa jenis tanaman lokal di Indonesia banyak dipergunakan oleh masyarakat dan befungsi sebagai tanaman obat ataupun suplemen tradisional. Tanaman atau bagian dari tanaman tersebut dapat dikategorikan sebagai plasma nutfah Indonesia (Putranto et al., 2012a). Plasma nutfah berupa tanaman tersebut berpotensi untuk difungsikan sebagai bahan pakan ternak baik yang diposisikan sebagai bahan pakan utama ataupun suplemen dengan tujuan tertentu. Tanaman katuk (Sauropus androgynus) dalam beragam bentuk dan formulasi telah disuplementasikan untuk meningkatkan status reproduksi ternak. Sedangkan jantung pisang telah lama dipergunakan oleh beberapa kalangan masyarakat guna memperbaiki status reproduksi.

Akan tetapi, potensi dan manfaat senyawa kimia alami dari tanaman khas Indonesia di atas belum banyak yang diketahui sehingga kajian tentang potensi kimia yang memiliki relevansi dengan efek fisiologi reproduksi sangat perlu dikembangkan lebih jauh (Handayani dan Ginting, 2011). Lebih jauh Handayani dan Ginting (2011) menyatakan bahwa kajian penapisan atau yang lebih dikenal dengan istilah skrining fitokimia merupakan suatu upaya menvalidasi keanekaragaman senyawa organik yang dibentuk oleh tumbuhan yang meliputi struktur kimia, biosintesa, perubahan serta metabolisme, penyebaran dan fungsi biologisnya.

Tanaman katuk telah cukup lama dipergunakan sebagai salah satu suplemen yang diberikan kepada ternak melalui campuran pakan ataupun air minum. Beberapa studi terdahulu, ekstrak daun katuk yang disuplementasikan melalui air minum pada ayam Burgo dapat mempengaruhi konsentrasi hormon estrogen serta jumlah folikel preheararchal (Putranto et al., 2012b). Selanjutnya Santoso et al. (2003, 2005) menemukan bahwa suplementasi ekstrak daun katuk berpengaruh sangat positif terhadap produksi telur baik dalam persen, butir maupun gram dan juga bahkan dapat meningkatkan jumlah produksi telur pada ayam petelur Leghorn.
Selanjutnya, hampir semua pohon pisang (Musa spp.) memiliki jantung pisang. Jantung pisang merupakan salah satu bahan makanan yang biasa dikonsumsi oleh masyarakat. Hal tersebut didukung oleh hasil studi terdahulu yang dilakukan oleh Kusumaningtyas et al. (2011), Abadiyah (2009) dan Robby et al. (2008). Selanjutnya, Kurniawan (2013) menyebutkan bahwa setiap jenis jantung pisang diketahui memiliki rasa gurih dan nikmat karena mengandung senyawa protein tinggi. Namun tidak semua jantung pisang dapat dikonsumsi karena beberapa jantung pisang ternyata mengandung banyak tanin. Di beberapa kalangan masyarakat, ada anggapan bahwa jantung pisang memiliki efek yang positif terhadap kesehatan reproduksi. Hal ini didukung oleh Anonimous (2013a) yang menyatakan bahwa jantung pisang atau banana flowers secara tradisional dipercaya sebagai lactating agent dan dapat meringankan rasa sakit saat menstruasi. Seperti halnya tanaman katuk, apabila asumsi tersebut benar maka jantung pisang dapat menjadi salah satu bahan pakan potensial untuk ternak guna meningkatkan status dan performa reproduksinya.

Penelitian ini dilakukan untuk mengevaluasi serta melakukan uji skrining fitokimia dari tanaman katuk dan jantung pisang sebagai upaya awal penapisan untuk mendalami kandungan steroid yang sering digunakan sebagai hormon reproduksi.

\section{MATERI DAN METODE}

Materi yang dipergunakan dalam studi ini adalah tanaman katuk segar yang dibagi atas bagian daun, batang dan campuran keduanya, serta 4 jenis jantung pisang yaitu jantung pisang raja (Musa textillia), jantung pisang serindit (Musa paradisiaca spp), jantung pisang batu (Musa acuminata balbisiana Colla) dan jantung pisang jantan (Musa paradisiaca spp) yang terdiri atas campuran bagian luar, tengah dan dalam. Bahan lain yang dipergunakan adalah kloroform amoniakal, $\quad \mathrm{HCl} \quad 2 \mathrm{~N}, \quad \mathrm{H}_{2} \mathrm{SO}_{4} \quad 2 \mathrm{~N}, \quad$ Pereaksi Liebermann-Buchard dan pelarut analitis. Alat yang dipergunakan antara lain gunting, 
tripleks, plastik, tali plastik, spidol, kertas, karton, timbangan analitik dan peralatan kimia.

Tahapan penelitian skrining fitokimia ini adalah : 1) persiapan berupa survei kebun daun katuk dan kebun pisang, pengurusan izin penelitian, penyediaan alat dan pengadaan pereaksi, 2) pengumpulan sampel bagian tanaman katuk dan jantung pisang yang berupa daun, batang, kelopak jantung dan bunga serta diikuti dengan identifikasi tanaman, dan tahapan berikutnya 3) penapisan/ fitokimia yang dilakukan pada bagian-bagian tanaman tersebut untuk mengetahui kandungan golongan senyawa steroid (Handayani dan Ginting, 2011; Putranto et al., 2012a).

Metode skrining kandungan senyawa steroid dilakukan menggunakan metode $\mathrm{Si}$ mes et al. (Handayani dan Ginting, 2011). Sebanyak $4 \mathrm{~g}$ sampel dihaluskan, direbus menggunakan $25 \mathrm{ml}$ etanol kemudian disaring dan diuapkan. Ekstrak yang tersisa dikocok dengan $5 \mathrm{ml}$ kloroform dan $5 \mathrm{ml}$ air sehingga akan terbentuk 2 lapisan yaitu lapisan kloform dengan kandungan steroid dan terpenoid serta lapisan air (flavonoid, fenolok, saponin).

\section{HASIL DAN PEMBAHASAN}

Pada Tabel 1 dapat dilihat hasil skrining senyawa metabolit steroid dari beberapa bagian tanaman katuk dan 4 jenis jantung pisang. Khusus tanaman katuk, sampel dibagi menjadi 3 bagian berdasarkan bagian tubuhnya yaitu 1) bagian daun, 2) bagian batang dan 3) campuran bagian daun dan batang. Sedangkan untuk sampel jantung merupakan campuran dari bagian luar, tengah dan dalam.

Hasil skrining senyawa metabolit steroid menggunakan larutan pereaksi Liebermann -Buchard yang dilakukan di Laboratorium Kimia Jurusan Pendidikan MIPA FKIP menunjukkan bahwa seluruh bagian tanaman katuk (daun, batang ataupun campuran keduanya) positif mengandung metabolit steroid. Hal tersebut terlihat dari hasil uji yang berwarna biru atau hijau (Gambar 1).
Tabel 1. Hasil skrining senyawa metabolit steroid dalam tanaman sampel

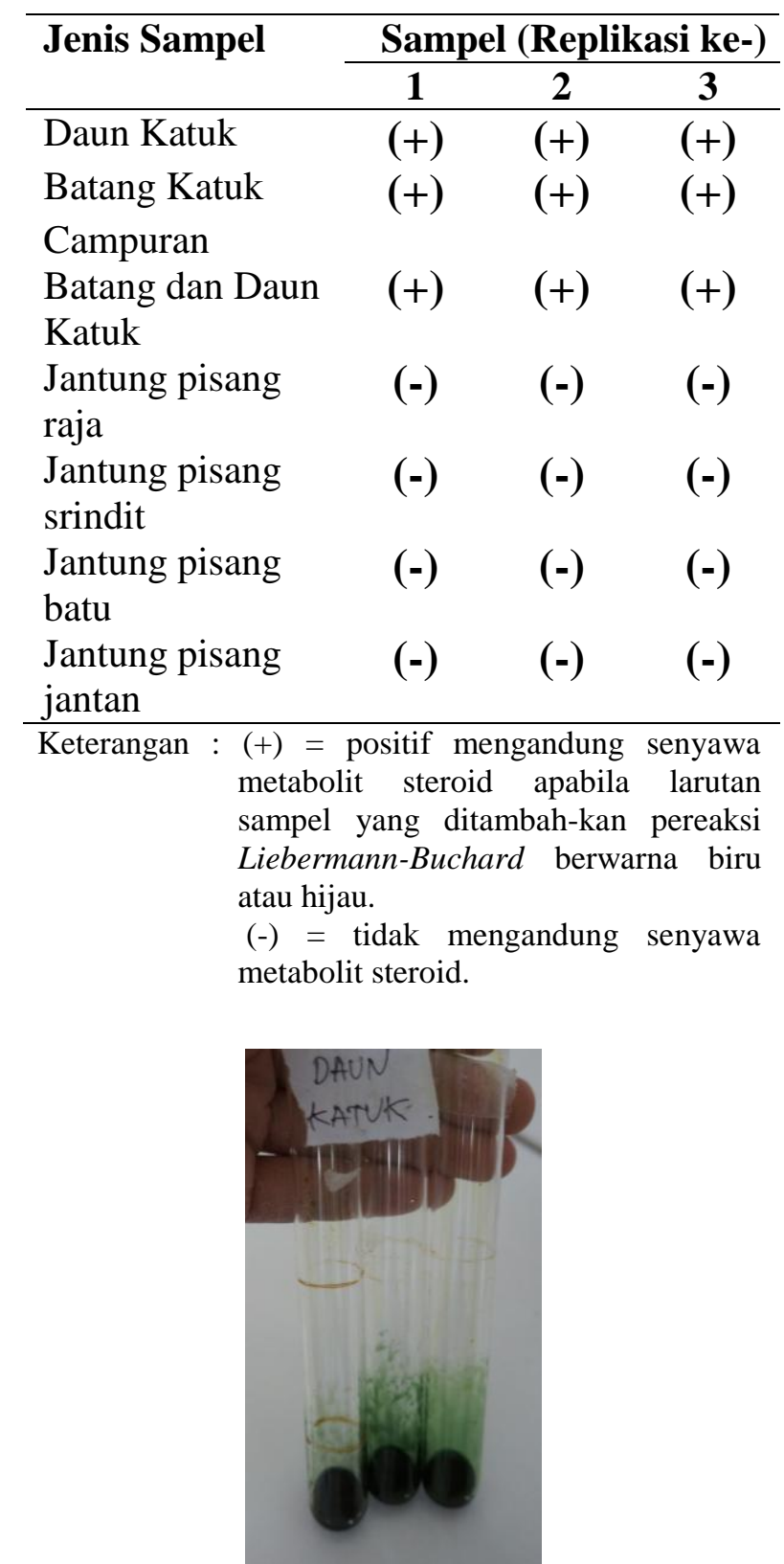

Gambar 1. Hasil skrining fitonutrien sampel daun katuk

Menurut Pitoyo (2013), daun katuk kaya akan zat besi, provitamin A dalam bentuk $\beta$-carotene, vitamin $C$, minyak sayur, protein dan mineral lainnya. Daun katuk tua terkandung air $10,8 \%$, lemak $20,8 \%$, protein kasar, 15,0\%, serat kasar 31,2\%, abu 12,7\%, dan BETN 10,2\%. Hasil penelitian menunjukkan bahwa dalam tepung daun katuk mengandung air $12 \%$, abu $8,91 \%$, lemak $26,32 \%$, protein $23,13 \%$, karbohidrat $29,64 \%$, 
$\beta$-carotene $165,05 \mathrm{mg} / 100 \mathrm{~g}$ dan energi 134,10 kal. Selanjutnya dikatakan bahwa dalam $100 \mathrm{~g}$ daun katuk mempunyai komposisi protein $4,8 \mathrm{~g}$, lemak $1 \mathrm{~g}$, karbohidrat 11 $\mathrm{g}$, kalsium $204 \mathrm{mg}$, fosfor $83 \mathrm{mg}$, besi 2,7 $\mathrm{mg}$, vitamin A $10370 \mathrm{SI}$, vitamin $\mathrm{B}_{1} 0,1 \mathrm{mg}$, vitamin C $239 \mathrm{mg}$, air $81 \mathrm{~g}$. Daun katuk mengandung khlorofil yang cukup tinggi, daun tua $65,8 \mathrm{spa} \mathrm{d} / \mathrm{mm}^{2}$, daun muda $41,6 \mathrm{spa}$ $\mathrm{d} / \mathrm{mm}^{2}$ dapat digunakan sebagai pewarna alami memberi warna hijau.

Agustal et al. (1997) menemukan bahwa daun katuk mengandung 6 senyawa utama yaitu monomethyl succinate dan cis-2-methyl cyclopentanol aseta, asam benzoat, asam fenil malonat, 2-pyrolidinon dan methyl pyroglutamate. Dalam bidang reproduksi, dinyatakan bahwa asam benzoat yang terkandung dalam daun katuk, akan dikonversikan menjadi estradiol benzoat di dalam tubuh. Estradiol benzoat berperan untuk meningkatkan fungsi reproduksi dan merangsang pertumbuhan folikel sehingga ayam dapat menghasilkan produksi telur yang lebih tinggi dan lebih efisien.

Beberapa pustaka lain menjelaskan bahwa daun katuk memiliki lima substansi dasar yang berasal dari kelompok asam lemak polyunsaturated dan berfungsi sebagai prekursor yang berperan dalam biosintesa eicosanoids (prostaglandin, prostacycline, thromboxane, lipoxins dan leukotrienes) dan terlibat dalam proses reproduksi dan fisiologi (Suprayogi, 2000; Ganong, 1993), serta kandungan 17-ketosteroid, androstan-17-one, 3-ethyl-3-hydroxy-5alpha berperan penting pada biosintesa hormon steroid betina (progesteron dan estradiol) (Despopoulos dan Silbernagi, 1991).

Menurut Anonimous (2013b), bahwa tanaman katuk juga memiliki pengaruh positif terhadap performa reproduksi jantan. Hal ini diketahui karena di dalam tanaman katuk terdapat zat aktif yang mampu merangsang sistensis hormon steroid progesteron dan testosteron sehingga akan membangkitkan vitalitas seksual, memacu kualitas dan kuantitas spermatozoa.

Ditambahkan oleh Pitoyo (2013), daun katuk juga mengandung senyawa metabolik sekunder yaitu monomrthyl succinate dan cis2-methyl cyclopentanol asetat (ester), asam benzoat dan asam fenil malonat (asam karboksilat), 2-pyrolodinon dan methyl pyroglutamate (alkaloid), saponin, flavonoid dan tanin. Senyawa-senyawa tersebut sangat penting dalam metabolisme lemak, karbohidrat dan protein dalam tubuh.

Data Tabel 1 memperlihatkan bahwa hasil yang negatif (-) pada ke-4 sampel jantung pisang. Diasumsikan bahwa pada sampel jantung pisang, hanya terdapat kandungan metabolit steroid yang sangat sedikit dan bahkan cenderung tidak ada (negatif). Hal ini terlihat dari hasil uji sampel yang tidak berwarna atau bening (Gambar 2).

Pada penelitian ini, bagian yang dijadikan sampel adalah jantung pisang. Jantung pisang adalah ujung bunga pisang yang tersisa saat bagian lainnya tumbuh menjadi buah pisang (Anonimous, 2013c). Lebih jauh

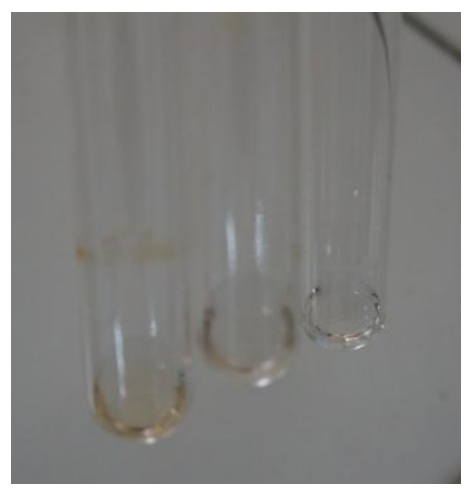

Gambar 2. Hasil skrining senyawa metabolit steroid sampel jantung pisang batu

dijelaskan bahwa jantung pisang merupakan sisa bunga pisang yang tidak lagi bisa menghasilkan buah. Biasanya, jantung pisang dipotong dari bagian tandannya agar buah pisang bisa tumbuh maksimal.

Jantung pisang mengandung zat gizi yang bermanfaat bagi tubuh berupa protein $(12,051 \%)$, karbohidrat $(34,831 \%)$ dan lemak total $(13,050 \%)$ (Anonimous, 2013c). Selain karbohidrat, jantung pisang juga mengandung protein, mineral (terutama fosfor, kalsium, dan besi), serta sejumlah vitamin A, B1 dan C. Komponen penting lainnya yang terdapat 
pada jantung pisang adalah serat pangan yang sangat bermanfaat bagi kesehatan.

Dalam $100 \mathrm{~g}$ jantung pisang segar hanya $25 \%$ saja bagian yang dapat dikonsumsi (Anonimous, 2013d). Lebih jauh diketahui bahwa jantung pisang mengandung energi 31 kkal, protein 1,2 g, lemak 0,3 g, karbohidrat $7,1 \mathrm{~g}$, kalsium $30 \mathrm{mg}$, fosfor $50 \mathrm{mg}$, zat besi 0 $\mathrm{mg}$, vitamin A $170 \mathrm{IU}$, vitamin B1 0,05 mg dan vitamin C $10 \mathrm{mg}$.

Walaupun hasil penelitian ini menunjukkan bahwa jantung pisang tidak mengandung senyawa metabolit steroid yang berguna untuk hormon reproduksi, ternyata jantung pisang mengandung senyawa saponin yang berfungsi menurunkan kolesterol dan meningkatkan kekebalan tubuh serta mencegah kanker. Juga mengandung flavonoid yang berfungsi antiradikal bebas, antikanker, dan anti aging. Selain itu juga mengandung yodium yang bisa mencegah penyakit gondok.

\section{KESIMPULAN}

Berdasarkan hasil penelitian skrining fitokimia diketahui bahwa tanaman katuk positif mengandung senyawa metabolit steroid sedangkan jantung pisang disinyalir tidak mengandung senyawa metabolit steroid yang berguna untuk merangsang biosistensis hormon steroid ternak betina.

\section{UCAPAN TERIMA KASIH}

Penulis dan tim peneliti mengucapkan terima kasih kepada Kementerian Pendidikan dan Kebudayaan Republik Indonesia. Direktorat Jenderal Pendidikan Tinggi yang telah mendanai penelitian ini melalui skema Penelitian Hibah Bersaing dengan nomor kontrak 155/UN30.10/LT/2013 tanggal 26 Maret 2013. Ucapan terima kasih juga ditujukan kepada Bapak/Ibu staf pengajar Program Studi Peternakan Fakultas Pertanian Universitas Bengkulu, Bapak Herman (Teknisi Laboratorium Peternakan), Yudha Prawira S.Pt, Sari Murti S.Pt, Rudy Hartono dan Budiono yang telah banyak membantu selama penelitian berlangsung.

\section{DAFTAR PUSTAKA}

Abadiyah, S. I. 2009. Pemanfaatan jantung pisang kepok (Musa paradisiaca) dengan konsentrasi yang berbeda terhadap mutu dendeng ikan mas (Cyprinus carpio). Skripsi. Fakultas Perikanan dan Ilmu kelautan Universitas Diponegoro, Semarang.

Agustal, A., Harapini, M. dan Chairul. 1997. Analisis kandungan kimia ekstrak daun katuk (Sauropus androgynus (L) Merr) dengan GCMS. Warta Tumbuhan Obat 3 (3): 31-33.

Anonimous. 2013a. What is banana flower.: http://www.wisegeek.org/what-is-abanana-flower.htm. [5 November 2013]

Anonimous. 2013b. Khasiat daun katuk dan kandungan gizinya. http://www. gen22.net/2013/03/khasiat-daun-katukdan-kandungan-gizinya. html. [5 November 2013]

Anonimous. 2013c. Manfaat dan kandungan tiap bagian. http://al-chemi.blogspot.com/2012/01/manfaat-dankandungan-tiap-bagian.html.[5 November 2013]

Anonimous. 2013d. Isi kandungan gizi jantung pisang segar komposis nutrisi bahan makanan. http://www.organisasi.org/1970/01/isi-kandungan-gizijantung-pisang-segar-komposisi-nutrisibahan-makanan.html. [5 November 2013]

Despopoulos, A. dan L. Silbernagi. 1991. Color Atlas of Physiology. 4rd Ed. Georg Thieme Verlag. Stuttgart, New York.

Ganong, W. F. 1993. Review of Medical Physiology. $6^{\text {th }}$ Ed. Prentice-Hall International Inc, San Fransisco.

Handayani, D. dan S. M. Ginting. 2011. Skrining fitokimia tumbuhan obat di kawasan taman Hutan Raya Raja Lelo Bengkulu. Laporan Penelitian Pembi- 
naan. Lembaga Penelitian Universitas Bengkulu. Bengkulu.

Kurniawan, P. 2013. Jantung pisang kaya serat tepat untuk diet. http://www. tabloidcempaka.com/index.php/read/ke sehatan/detail/188/Jantung-PisangKaya-Serat-Tepat-untuk-Diet.html. $\quad$ [9 September 2013].

Kusumaningtyas, D. R., W. D. P. Rengga dan H. Suyetno. 2011. Pengolahan limbah tanaman pisang (Musa paradisiaca) menjadi dendeng dan abon jantung pisang. Laporan Praktek Kerja Lapangan. Fakultas Teknik, Fakultas Matematika dan Ilmu Pengetahuan Alam Universitas Negeri, Semarang.

Pitoyo, J. 2013. Kandungan daun katuk. http://kandungan-daun-katuk.blog spot.com. [5 November 2013]

Putranto, H. D., S. M. Ginting dan Nurmeliasari. 2012a. Studi fitonutrien dan Utilisasi Mikronutrisi Suplemen Tradisional untuk Optimalisasi Status Reproduksi Ruminansia Potong dan Ketahanan Pangan di Provinsi Bengkulu. Proposal Hibah Bersaing. Lembaga Penelitian Universitas Bengkulu.

Putranto, H. D., J. Setianto, U. Santoso, Warnoto, Nurmeliasari, dan A. Zueni. 2012b. Estradiol-17 $\beta$ hormone concentration and follicles number in exotic burgo chicken supplemented by katuk leaves extract (Sauropus androgynus). Biodiversitas Journal of Biological Science 13 (1): 1-6

Robby, D., W. Arius, dan H. Erwan. 2008. Formulasi pembuatan naken balls berbahan dasar daging ayam dan jantung pisang sebagai sumber serat pangan. Laporan Penelitian Departemen Ilmu dan Teknologi Pangan. Fakultas Teknologi Pertanian. Institut Pertanian Bogor, Bogor.

Santoso, U., J. Setianto, and T. Suteki. 2005. Effect of Sauropus androgynus extract on egg production and lipid metabolism in layers. Asian-Aust. J. Anim. Sci. Vol 18 (3): 364.

Santoso, U., J. Setianto, T. Suteky, dan Y. Fenita. 2003. Penggunaan ekstrak daun katuk untuk meningkatkan efisiensi produksi dan kualitas telur yang ramah lingkungan pada ayam Leghorn. Laporan Penelitian Hibah Bersaing Lanjutan. Lembaga Penelitian Universitas Bengkulu, Bengkulu.

Suprayogi, A. 2000. Studies on the biological effects of Sauropus androgynus (L) Merr.: Effects on milk production and the possibilities of induced pulmonary disorder in lactating sheep. Disertasi. University Gottingen, Germany. 